\title{
Strategi Bisnis dalam Praktik Manajemen Laba pada Perusahaan Manufaktur di Indonesia
}

\author{
Permata Ayu Widyasari, Senny Harindahyani, Felizia Arni Rudiawarni \\ Departemen Akuntansi Fakultas Bisnis dan Ekonomika Universitas Surabaya \\ Jl. Raya Kali Rungkut Surabaya, 60292, Indonesia
}

\begin{abstract}
Keywords:

Audit Quality;

Business Strategy;

Defender; Earnings

Management

JEL Classification:

G30, M21, M41

This study investigated whether firm's business strategy is associated with real and accrual earnings management. It applied by Miles $\mathcal{E}$ Snow (1978) business strategy typology and classified business strategy into two dominant and contrast strategy, prospector and defender. Business strategy is how the company make decision to compete with its competitors and to sell its products. Compare with prospectors, Defenders have motivation to engage in earnings management with the purpose of maintain its reputation as stable company and fulfil the investor's expectation. Furthermore, this study also examined whether audit quality can decrease real and accrual earnings management. The sample were used in this study are manufacturing firms that are listed in Indonesia Stock Exchange in period 2011-2014. Hypotheses were tested using multiple linear regressions. Our findings show that defender has higher absolute real earnings management compare to prospector, especially for profit firms. However, absolute real earnings management can be decreased along with the increase of audit quality. Such findings could be a consideration for the investors. On the other hand, business strategy does not associate with accrual earnings management.
\end{abstract}

Kata Kunci:

Kualitas Audit;

Strategi Bisnis;

Defender;

Manajemen Laba

\section{ABSTRAK}

Studi ini bertujuan untuk meneliti pengaruh strategi bisnis perusahaan terhadap manajemen laba riil maupun manajemen laba akrual. Strategi bisnis yang digunakan mengacu pada tipologi Miles dan Snow (1978) dan mengkalisifikasikan sample kedalam dua jenis strategi bisnis yang dominan dan kontras yaitu prospector dan defender. Strategi bisnis mencakup serangkaian keputusan manajemen untuk dapat bersaing dalam suatu industri dan memasarkan produknya. Dibandingkan dengan prospector, defender mempunyai motif untuk melakukan manajemen laba dengan tujuan untuk menjaga reputasinya sebagai perusahaan yang stabil dan untuk memenuhi ekspektasi dari para investor. Oleh karena itu, strategi bisnis dapat memberikan dampak terhadap besarnyaender mem laba yang dimiliki oleh perusahaan. Defender memiliki motivasi untuk menjaga reputasinya sebagai perusahaan stabil yang cenderung memenuhi ekspektasi investornya, Selanjutnya diteliti apakah kualitas audit mampu menekan perilaku manajemen laba dari perusahaan. Studi ini dilakukan pada perusahaan manufaktur yang terdaftar di BEI periode 2011-2014 dengan menggunakan regresi linier berganda. Temuan menunjukkan bahwa defender memiliki besaran manajemen laba riil yang lebih besar dibanding dengan prospector, terutama pada perusahaan profit. Namun dengan kualitas audit yang baik, besaran manajemen laba riil ini dapat ditekan. Temuan tersebut dapat menjadi pertimbangan oleh para investor. Di sisi lain, strategi bisnis tidak berpengaruh pada manajemen laba akrual. 


\section{Jurnal Keuangan dan Perbankan | KEUANGAN}

Vol. 21, No. 3, Juli 2017: 397-411

Penelitian-penelitian terdahulu menemukan bahwa fenomena manajemen laba terdapat pada hampir setiap laporan keuangan yang dipublikasikan oleh perusahaan (Dechow et al., 1995; Holthausen et al., 1995; DeAngelo et al., 2000). Teori keagenan (Jensen \& Meckling, 1976) menunjukkan bahwa terdapat konflik kepentingan antara pihak manajemen (sebagai agent) dengan pihak pemilik (sebagai principal). Jika kepentingan manajemen bertolak belakang dengan kepentingan pemilik, maka manajemen akan cenderung berperilaku oportunistik demi melindungi kepentingannya sendiri. Tindakan oportunis tersebut dilakukan dengan cara memilih kebijakan akuntansi tertentu, sehingga laba perusahaan dapat diatur, dinaikkan, atau diturunkan sesuai dengan keinginannya (Yendrawati \& Nugroho, 2012). Kondisi ini ditambah dengan adanya asimetri informasi menyebabkan pihak manajemen berupaya untuk memanfaatkan fleksibilitas (diskresi) yang dimilikinya untuk melaporkan laba sesuai dengan target tertentu yang diinginkannya.

Banyak penelitian yang dilakukan terkait motivasi manajer untuk melakukan manajemen laba, baik dari sudut pandang teori akuntansi positif (Watts \& Zimmerman, 1986), manajemen laba dikaitkan dengan reaksi pasar (Bartov et al., 2001; Matsumoto, 2002; Arni \& Sulistiawan, 2015), terkait dengan kebijakan dividen (Daniel et al., 2008), dan termasuk dari sudut pandang laporan keuangan itu sendiri (Barton \& Simko, 2002).

Selain dari berbagai motivasi tersebut, strategi bisnis memiliki peran besar dalam menstimulasi manajer untuk melakukan manajemen laba (Bentley et al., 2013; Houqe et al., 2013). Berbicara tentang peranan manajer tidak terlepas dari peranan mereka dalam menentukan strategi bisnis perusahaan. Dalam kapasitasnya sebagai penyedia laporan keuangan di satu sisi dan sebagai penentu strategi bisnis perusahaan, maka kualitas laba secara potensial juga merupakan fungsi strategi bisnis.
Mengacu pada riset-riset terdahulu, studi ini berfokus pada implementasi strategi, dengan menggunakan tipologi dari Miles et al. (1978). Tipologi dari Miles et al. (1978) mampu memberikan karakter mengenai organisasi sebagai sebuah sistem yang lengkap, khususnya terkait dengan orientasi strategi (Snow \& Hrebiniak, 1980) dalam Houqe et al. (2013). Miles et al. (1978) membagi strategi bisnis perusahaan ke dalam 4 kategori berdasarkan orientasi pasarnya, yaitu prospector, defender, analyzer dan reactor. Tapi reactor sulit untuk diidentifikasi sehingga penelitian terkait strategi bisnis hanya berfokus 3 strategi yang bisa diidentifikasi (Bentley et al., 2013). Pengelompokkan strategi tersebut merupakan sebuah kontinum dengan menempatkan prospector dan defender pada kedua ujungnya (Bentley et al., 2013). Studi ini berfokus pada 2 strategi yang berada di ujung kontinum tersebut karena hal ini konsisten dengan riset-riset sebelumnya baik dalam bidang manajemen maupun akuntansi (Bentley et al., 2013). Lebih lanjut Miles \& Snow (1978) dalam Houqe et al. (2013) menyatakan bahwa prospector dan defender adalah tipe strategi yang paling dominan.

Prospector adalah perusahaan yang memiliki komitmen terhadap inovasi dan mencari peluang pasar yang baru. Prospector lebih berfokus pada inovasi dibanding dengan efisiensi (Bentley et al., 2013; Houqe et al., 2013). Sedangkan defender berfokus pada efisiensi produksi dan distribusi barang ataupun jasa. Mereka mempertahankan pasar yang ada saat ini dibanding mencari peluang pasar baru (Miles \& Snow, 1978 dalam Houqe et al., 2013). Defender berfokus pada efisiensi dan bukan pada inovasi (Houqe et al., 2013).

Berdasarkan riset-riset terdahulu (Bentley et al., 2013; Houqe et al., 2013) kedua jenis strategi bisnis ini berpengaruh terhadap kualitas laporan keuangan. Namun demikian hasil penelitian tersebut masih belum konsisten terkait apakah prospector ataukah defender yang memiliki kualitas laporan keuangan yang lebih baik. Auditor adalah pihak 


\section{Strategi Bisnis dalam Praktik Manajemen Laba pada Perusahaan Manufaktur di Indonesia \\ Permata Ayu Widyasari, Senny Harindahyani, Felizia Arni Rudiawarni}

independen yang diharapkan mampu menjaga kredibilitas laporan keuangan. Dalam melaksanakan tugasnya, auditor berpegang pada etika profesi yang menuntut mereka untuk bersikap dan bertindak profesional. Diharapkan dengan peranan auditor yang maksimal, maka derajat kredibilitas laporan keuangan dapat meningkat di mata para penggunanya.

Di sisi lain, tidak dipungkiri bahwa kualitas audit berbeda-beda untuk masing-masing audit firms (DeAngelo, 1981; Francis et al., 1999). Bartov et al. (2001) menyatakan bahwa auditor yang berkualitas tinggi lebih memilih untuk melaporkan kesalahan dan ketidaksesuaian laporan keuangan yang diauditnya dan tidak menerima adanya praktik akuntansi yang dipertanyakan. Oleh sebab itu, auditor yang berkualitas tinggi diharapkan lebih mampu mendeteksi adanya praktik manajemen laba (Becker et al., 1998). Berdasarkan penelitian-penelitian terdahulu, auditor dari Kantor Akuntan Publik (KAP) BIG4 dipercaya memiliki kualitas audit yang lebih tinggi dibanding auditor lainnya (DeAngelo, 1981; Watts \& Zimmerman, 1986). KAP BIG4 memiliki insentif yang lebih besar untuk menghasilkan atau mempertahankan kualitas audit mereka terkait dengan berbagai hal, terutama pertimbangan reputasi yang harus mereka pertahankan (Caneghem, 2004; Chung et al., 2005).

Berdasarkan pada uraian tersebut, studi yang dilakukan adalah untuk mengetahui pemilihan strategi bisnis perusahaan dalam memengaruhi praktik manajemen laba dan apakah auditor mampu berperan dalam mengurangi praktik manajemen laba yang dilakukan oleh perusahaan. Penelitian yang berfokus pada strategi bisnis dan kaitannya dengan praktik manajemen laba masih jarang dilakukan di Indonesia. Perbedaan dengan penelitian sebelumnya adalah penelitian ini menempatkan kualitas audit sebagai variabel moderasi, karena relevan dengan peran dan fungsi penugasan audit sebagai salah satu jenis penugasan asuransi yang dapat menambah tingkat keandalan laporan keuangan bagi pengambilan keputusan ekonomi penggunannya.

Penelitian ini diharapkan memberikan kontribusi teoritis dalam bidang manajemen laba dan strategi bisnis, memperkaya metode kategorisasi untuk strategi bisnis, dan memberikan kontribusi secara keilmuan karena menggabungkan riset-riset di bidang manajemen strategi, kualitas laporan keuangan, dan audit. Dengan mengacu pada metode yang digunakan oleh Snow \& Hambrick (1980) dalam Houqe et al. (2013) dan Bentley et al. (2013), penelitian ini diharapkan dapat memberikan indikator yang objektif terkait strategi bisnis yang dipilih oleh perusahaan.

\section{PENGEMBANGAN HIPOTESIS}

\section{Manajemen Laba Akrual dan Riil}

Manajemen laba merupakan pilihan manajer terkait dengan kebijakan akuntansi maupun tindakan nyata yang memengaruhi laba untuk mencapai jumlah laba yang diinginkan (Scott, 2015). Jadi manajemen laba melibatkan teknik akrual maupun aktivitas riil. Akrual terdiri dari non akrual diskresioner dan akrual diskresioner. Akrual diskresioner merupakan akrual yang bisa dikendalikan oleh pihak manajemen. Menurut Healy (1985) manajer cenderung melakukan manajemen laba melalui akrual diskresioner. Berbagai studi meneliti mengenai akrual diskresioner dan bagaimana metode-metode untuk bisa memisahkan antara non akrual diskresioner dan akrual diskresioner (Jones, 1991; Dechow et al., 1995; Kothari et al., 2005). Berbagai penelitian menguji bagaimana perusahaan melakukan manajemen laba melalui akrual untuk mencapai target laba tertentu (Burgstahler \& Dichev, 1997; Degeorge et al., 1999; Bartov et al., 2002).

Graham et al. (2005) dan Cohen et al. (2008) menemukan bahwa setelah era Sarbanes-Oxley Act (SOX) manajer cenderung menghindari manajemen laba berbasis akrual dan beralih pada mana- 


\section{Jurnal Keuangan dan Perbankan | KEUANGAN}

Vol. 21, No. 3, Juli 2017: 397-411

jemen laba riil. Alasannya adalah manajemen laba riil lebih sulit dideteksi oleh auditor dan regulator. Roychowdhury (2006) menemukan bahwa perusahaan menggunakan beberapa jenis manajemen laba riil untuk memenuhi target laba tertentu atau menghindari rugi.

\section{Strategi Bisnis}

Strategi bisnis terkait dengan rangkaian keputusan manajemen untuk dapat bersaing dalam suatu industri dan memasarkan produknya (Walker \& Ruekert, 1987; Varadarajan \& Clark, 1994). Bentley et al. (2013) dan Houqe et al. (2013) mengungkapkan bahwa strategi bisnis dapat berperan dalam menstimulasi keputusan manajer untuk malakukan manajemen laba. Oleh karena itu, strategi bisnis yang dipilih oleh manajemen dapat memberikan dampak terhadap besarnya laba yang dimiliki oleh perusahaan.

Berdasarkan tipologi dari Miles \& Snow (1978, 2003), penelitian ini hanya menggunakan strategi prospector dan defender karena merupakan tipe strategi paling dominan dan kontras (Bentley et al., 2013; Houqe et al., 2013). Defender diduga melakukan manajemen laba lebih tinggi daripada prospector mengingat ketidakmampuannya dalam menghadapi risiko dan menghadapi ketidakpastian yang terjadi dalam bisnis (Higgins et al., 2013). Prioritas yang diutamakan adalah menjaga reputasinya sebagai perusahaan yang stabil, terutama dihadapan pelanggan dan pemegang sahamnya (Houqe et al., 2013; Higgins et al., 2013).

Houqe et al. (2013) menggunakan 3 teori untuk menggambarkan hubungan strategi bisnis yang dilakukan oleh defender dengan manajemen laba, yaitu agency theory (Jensen \&Meckling, 1976), political cost theory (Watts \& Zimmerman, 1978), dan transaction cost theory (Coase, 1937). Dalam Houqe et al. (2013), Jensen \& Meckling (1976) mengungkapkan bahwa manajer pada dasarnya mengambil tindakan berdasarkan 2 kondisi, yaitu jika kepentingannya sama dengan pemilik (principal) atau tidak. Tindakan manajer jika kepentingannya selaras dengan kepentingan pemilik, maka manajer mendahulukan kepentingan perusahaan dengan tetap mengutamakan capaian bagi dirinya sendiri. Sebaliknya, jika kepentingannya tidak selaras dengan kepentingan pemilik, maka manajer akan cenderung memaksimalkan kepentingannya sendiri (Houqe et al., 2013). Pada political cost theory dan transaction cost theory manajer berusaha untuk menjaga laba perusahaan agar tidak menjadi sorotan negatif masyarakat dan pemerintah dengan melakukan kebijakan akuntansi secara konservatif, misal income-decreasing accounting policies (Scott, 2015), dan tidak menimbulkan risiko bagi investor dengan menstabilkan beban-beban transaksinya.

Defender memiliki motivasi untuk menjaga reputasinya sebagai perusahaan stabil yang cenderung memenuhi ekspektasi investornya. Sedangkan prospector cenderung untuk mengutamakan kepentingannya dalam berinovasi dan mencari peluang pasar baru, sehingga berakibat pada lebih rendahnya pemenuhan ekspektasi investornya (Houqe et al., 2013). Kondisi tersebut mengakibatkan prospector tidak memiliki tekanan untuk melakukan manajemen laba jika dibandingkan dengan defender. Hasil penelitian Houqe et al. (2013) membuktikan bahwa terdapat hubungan antara pemilihan strategi bisnis defender dengan lebih tingginya tingkat manajemen laba karena ekspektasi investor terhadap perusahaan juga semakin tinggi. Dari kajian konsep dan empiris tersebut, maka ditarik hipotesis 1 sebagai berikut:

$\mathrm{H}_{1}$ : perusahaan dengan strategi bisnis defender lebih cenderung melakukan manajemen laba dibandingkan dengan perusahaan dengan strategi bisnis prospector.

\section{Kualitas Audit}

Hasil penelitian DeAngelo (1981) mengungkapkan bahwa semakin besar audit firms (KAP), memberikan kualitas audit yang lebih tinggi. Nama 


\section{Strategi Bisnis dalam Praktik Manajemen Laba pada Perusahaan Manufaktur di Indonesia \\ Permata Ayu Widyasari, Senny Harindahyani, Felizia Arni Rudiawarni}

besar KAP (BIG4) dapat menjamin kualitas audit yang diberikan, dalam artian penugasan audit yang dilakukan sesuai dengan standar audit, akuntansi, etika, serta standar lain yang relevan dengan kontrak penugasan audit (Lee \& Lee, 2013). Pemilihan BIG4 dalam pengklasifikasian KAP bereputasi mengacu pada penelitian-penelitian sebelumnya yang diantaranya dilakukan oleh DeAngelo (1981), Rusmin (2010), Siregar et al. (2012), Lee \& Lee (2013), dan Ettredge et al. (2014). Disamping itu, Indonesia belum memiliki direktori khusus yang mengklasifikasikan KAP secara resmi berdasarkan kategori reputasinya baik oleh IAPI, lembaga sejenis, maupun regulator.

Sesuai dengan tujuan audit dalam SA 315, hasil evaluasi auditor sebagai pihak independen dapat meningkatkan keandalan informasi dalam suatu laporan keuangan (Shireenjit, 2007; Collings, 2011). Pernyataan DeAngelo (1981) serta Lee \& Lee (2013) menegaskan bahwa kualitas audit menunjukkan kemampuan auditor untuk mendeteksi kesalahan penyajian dalam laporan keuangan agar informasi akuntansi memberikan nilai relevansi yang tinggi bagi penggunanya. Caneghem (2004), Chung et al. (2005), dan Francis \& Yu (2009) berargumentasi bahwa KAP BIG4 menyediakan dan memberikan jaminan kualitas audit yang tinggi karena banyaknya jumlah klien, tersedianya sumber daya manusia maupun teknologi yang berpeluang lebih besar untuk mendeteksi terjadinya kesalahan penyajian material, dan kesadaran lebih untuk menjaga reputasinya. Disisi lain, hasil penelitian Harindahyani (2015) mengungkapkan bahwa KAP Non BIG4 lebih mempertimbangkan perspektif utilitarian dalam mengartikan profesionalitas, yaitu mengutamakan ketepatan waktu dalam penyelesaian penugasan audit daripada kelengkapan pendokumentasian audit.

Kualitas audit memberikan tingkat keyakinan yang tinggi bagi penggunanya, karena auditor diyakini dapat mengurangi bias yang terjadi pada laporan keuangan. Hasil penelitian Rusmin (2010) membuktikan bahwa tingkat manajemen laba yang dilakukan oleh klien auditor spesialis lebih rendah dan auditor dari KAP BIG4 dapat mengungkapkan terjadinya manajemen laba lebih baik daripada KAP Non BIG4. Auditor berkualitas tinggi akan melakukan pengujian audit yang efektif untuk mendeteksi terjadinya manajemen laba, tidak menerima praktik akuntansi yang dipertanyakan, dan cenderung melaporkan kecurangan serta ketidakpatuhan standar (Bartov et al., 2001). Hasil penelitian Becker et al. (1998) membuktikan bahwa auditor yang berkualitas tinggi memiliki klien dengan tingkat manajemen laba lebih rendah karena kemampuannya untuk mendeteksi praktik manajemen laba. Dari kajian konsep dan empiris tersebut, maka ditarik hipotesis 1 sebagai berikut:

$\mathrm{H}_{2}$ : kualitas audit mampu memoderasi pengaruh strategi bisnis dengan manajemen laba.

\section{METODE}

Penelitian ini menggunakan data dari perusahaan manufaktur yang terdaftar di bursa Indonesia selama periode 2011-2014. Penelitian ini mendefinisikan bisnis strategi sebagai cara sebuah perusahaan untuk bertahan dan berkompetisi dalam industri. Oleh karena itu, perusahaan manufaktur dipilih menjadi sampel karena dapat menggambarkan implementasi bisnis strategi sebuah perusahaan dalam menangani perubahan marketproduct, pelanggan, dan pesaing. Disamping itu, pemilihan industri manufaktur sebagai obyek studi ini didasarkan pada riset sebelumnya, dimana industri manufaktur memiliki tingkat manajemen laba yang lebih tinggi dibanding industri lainnya (Rusmin, 2010; Kuan et al., 2010).

\section{Penentuan Manajemen Laba}

Manajemen laba diestimasi dengan 2 pendekatan, yaitu dengan pendekatan manajemen laba akrual dan manajamen laba riil. Manajemen laba 


\section{Jurnal Keuangan dan Perbankan | KEUANGAN}

Vol. 21, No. 3, Juli 2017: 397-411

akrual dihitung dengan model performance matched discretionary accrual oleh Kothari et al. (2005) seperti yang diaplikasikan oleh Prawitt et al. (2009). Manajemen laba riil dihitung dengan mengadopsi model Roychowdhury (2006) yang telah diaplikasikan oleh Cohen \& Zarowin (2010).

Manajemen laba akrual tercermin dari abnormal akrual yang diperoleh dari residual regresi formula (1). Model dipilih karena menggunakan ROA sehingga dapat mengontrol efek performance on measured discretionary accruals. Model tersebut diregresikan secara terpisah per tahun dan per industri. Penelitian ini menggunakan absolut residual untuk menunjukan besar manajemen laba akrual.

$\frac{\mathrm{TA}_{\mathrm{it}}}{\mathrm{A}_{\mathrm{it}-1}}=\beta_{0}+\beta_{1} \frac{1}{\mathrm{~A}_{\mathrm{it}-1}}+\beta_{2} \frac{\Delta \mathrm{REV}_{\mathrm{it}}-\Delta \mathrm{AR}_{\mathrm{it}}}{\mathrm{A}_{\mathrm{it}-1}}+\beta_{3} \frac{\mathrm{PPE}_{\mathrm{it}}}{\mathrm{A}_{\mathrm{it}-1}}+\beta_{4} \frac{\mathrm{NI}_{\mathrm{it}}}{\mathrm{A}_{\mathrm{it}-1}}+\varepsilon \ldots . .(1)$

TA $_{\text {it }} \quad$ : Total akrual (laba bersih - arus kas operasi)

Ait-1 : aset tahun lalu

“REVit : selisih pendapatan tahun $\mathrm{t}$ dan $\mathrm{t}-1$

“ARit : selisih piutang tahun $\mathrm{t}$ dan $\mathrm{t}-1$

PPEit : aset tetap tahun $\mathrm{t}$

NIit : laba bersih tahun $t$

Penelitian ini fokus pada salah satu indikator manajemen laba riil yaitu manipulasi penjualan melalui percepatan waktu penjualan dengan meningkatkan harga diskon atau memberikan kredit ringan. Hal tersebut dapat tercermin dari tingkat arus kas dari operasi yang abnormal. Abnormal arus kas operasional diambil dari residual regresi formula (2). Model tersebut diregresikan untuk setiap tahun dan setiap industri. Penelitian ini menggunakan absolut residual untuk menunjukan besar manajemen laba riil.
$\frac{\mathrm{CFO}_{\mathrm{it}}}{\mathrm{A}_{\mathrm{it}-1}}=\beta_{0}+\beta_{1} \frac{1}{\mathrm{~A}_{\mathrm{it}-1}}+\beta_{2} \frac{\text { SALES }_{\mathrm{it}}}{\mathrm{A}_{\mathrm{it}-1}}+\beta_{3} \frac{\Delta \text { SALES }_{\mathrm{it}}}{\mathrm{A}_{\mathrm{it}-1}}+$

CFOit : arus kas operasi

Salesit : penjualan

"Salesit: perubahan sales tahun $\mathrm{t}-1$

\section{Penentuan Bisnis Strategi}

Bisnis strategi diklasifikasikan menjadi prospector dan defender menurut definisi Miles et al. (1978). Pengklasifikasikan bisnis strategi berdasarkan penjumlahan skor 12 komponen bisnis strategi yang diadopsi dari Juanda (2007), Jermias (2008), Bentley et al. (2013), dan Higgins et al. (2013). Komponen-komponen tersebut merupakan karakteristik yang menggambarkan strategi bisnis suatu perusahaan.

Setiap komponen diranking per tahun serta per industri dan diberi skor berdasarkan kuantilnya. Untuk observasi yang berada dikuantil tertinggi akan diberi skor 5, dan yang berada pada kuantil kedua terendah diberi nilai 1. Cara penilaian ini diberikan untuk semua komponen kecuali, efisiensi penggunaan aset dan intensitas capital. Dua komponen tersebut diberi penilai secara terbalik. Selajutnya skor ranking tersebut dijumlah, sehingga setiap observasi mempunyai nilai minimum 12 dan maksimum 60. Pengkategorian strategi bisnis bergantung pada nilai median sampel. Untuk observasi yang mempunyai nilai total sama dengan atau di bawah median, dikategorikan menjadi defender (dummy $=1)$. Untuk observasi yang mempunyai nilai total di atas median, dikategorikan menjadi prospector $($ dummy $=0)$. 


\section{Strategi Bisnis dalam Praktik Manajemen Laba pada Perusahaan Manufaktur di Indonesia}

Permata Ayu Widyasari, Senny Harindahyani, Felizia Arni Rudiawarni

Tabel 1. Definisi Operasional dan Pengukuran Vaiabel

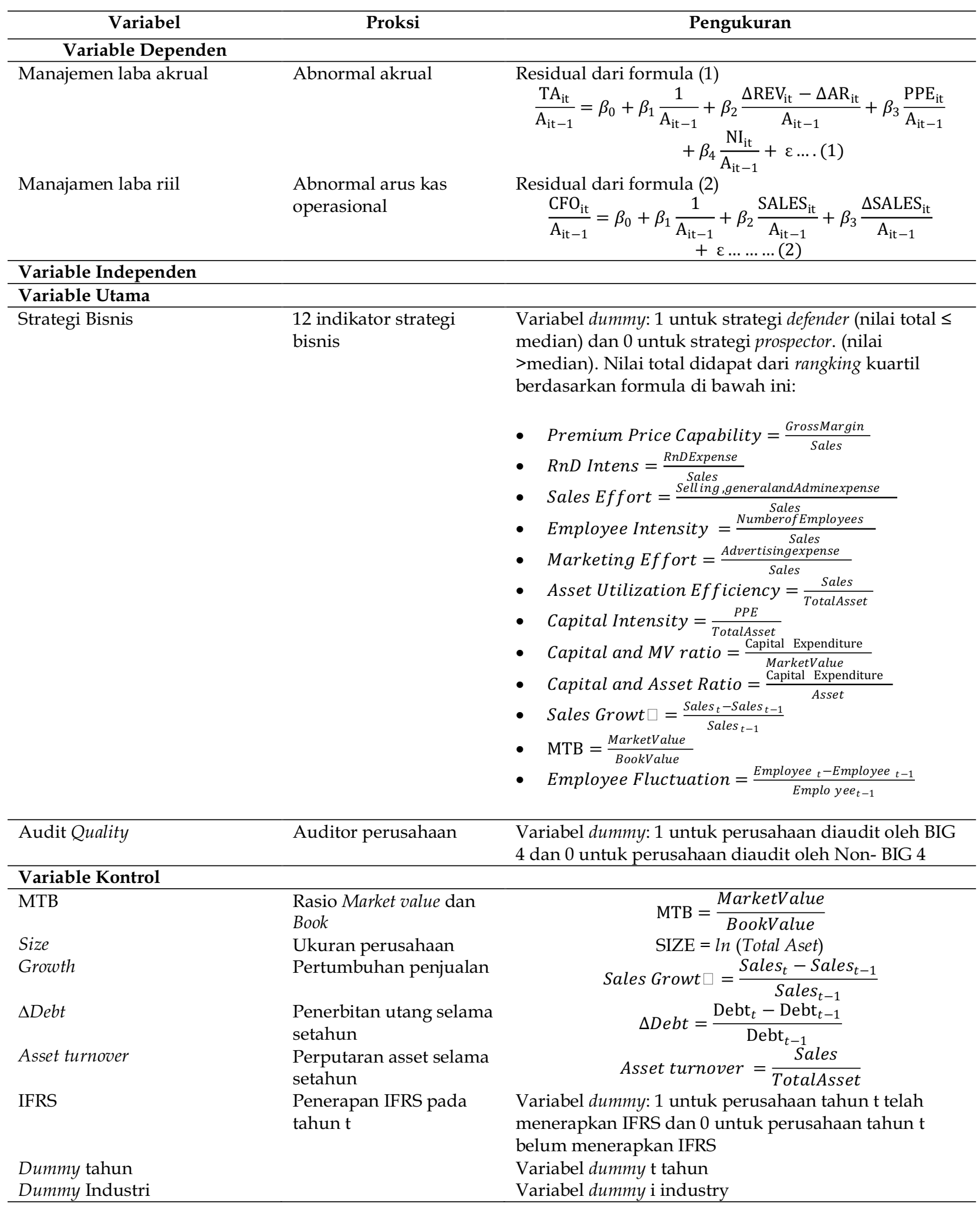




\section{Jurnal Keuangan dan Perbankan | KEUANGAN}

Vol. 21, No. 3, Juli 2017: 397-411

\section{Pengujian Hipotesis}

Studi ini menggunakan variabel dependen manajemen laba akrual dan manajemen laba riil. Variabel independen yang digunakan adalah bisnis strategi. Studi ini juga menggunakan variable BIG4 sebagai proksi kualitas audit untuk memoderasi hubungan strategi bisnis terhadap manajemen laba. Variabel kontrol yang digunakan adalah rasio nilai market dan nilai buku, ukuran perusahaan, pertumbuhan, penerbitan utang, intensitas model (perputaran aset), IFRS, dan kontrol tahun dan industri. Pengujian hipotesis 1 dilihat dari signifikansi $\beta_{1}$ dan pengujian hipotesis 2 dilihat dari signifikansi $\beta_{3}$.

$\begin{aligned} \text { AbsAbAcc }= & \beta_{0}+\beta_{1} \text { STRAT }+\beta_{2} \text { BIG } 4+\beta_{3} \text { STRAT }^{*} \\ & \text { BIG }+\beta_{4} \mathrm{Mtb}+\beta_{5} \text { LnSize }+\beta_{6} \text { growth } \\ & +\beta_{7} \text { ddebt }+\beta_{8} \text { turnover }+\beta_{9} \text { IFRS }+ \\ & b_{10} \text { AbsAbAcct } 1+b_{11-13} \text { YearDummies } \\ & +\beta_{14-15} \text { Industry Dummies }+ \text { e } \ldots \text { (3) } \\ \text { AbsREMCFO= } & \beta_{0}+\beta_{1} \text { STRAT }+\beta_{2} \text { BIG } 4+\beta_{3} \text { STRAT* } \\ & \text { BIG }++\beta_{4} \mathrm{Mtb}+\beta_{5} \text { LnSize }+ \\ & \beta_{6} \text { growth }+\beta_{7} \text { ddebt }+\beta_{8} \text { turnover }+ \\ & \beta_{9} \text { IFRS }+\beta_{10-12} \text { Year Dummies }+\beta_{13-} \\ & { }_{15} \text { Industry Dummies }+\varepsilon \ldots \ldots . . .(4)\end{aligned}$

\section{Keterangan:}

$\begin{array}{ll}\text { AbsAbAcc } & \text { : akrual Diskresioner } \\ \text { AbsREMCFO } & \begin{array}{l}\text { : manajemen laba riil dari mani- } \\ \text { pulasi penjualan }\end{array} \\ \text { STRAT } & \begin{array}{l}\text { : bisnis strategi, prospector (0) dan } \\ \text { defender (1) }\end{array} \\ & \text { : auditor perusahaan, untuk per- } \\ \text { BIG4 } & \text { usahaan yang diadit BIG4 (1) } \\ & \text { untuk perusahaan yang diaudit } \\ & \text { non BIG4 (0) } \\ \text { Mtb } & : \text { rasio market value dan book } \\ \text { Ln Size } & : \text { ukuran perusahaan yang dihi- } \\ & \text { tung dari total asset perusahaan } \\ & \text { i tahun }\end{array}$

Debt : penerbitan utang

Turnover : perputaran asset (total penjualan dibagi total aset)

IFRS

: penerapan IFRS (dummy, 1 bagi tahun penerapan IFRS, 0 bagi tahun tanpa penerapan IFRS)

AbsAbAcct-1 : abnormal akrual t-1

YEAR

: dummy tahun observasi adalah tahun $\mathrm{t}$.

IND

: dummy jenis industri perusahaan $\mathrm{i}$ tahun $\mathrm{t}$.

\section{HASIL}

\section{Hasil Statistik Deskriptif \& Pengujian Model}

Tabel 2 menunjukkan hasil deskripsi statistik, sedangkan hasil uji hipotesis terkait dengan manajemen laba riil dan akrual nampak pada Tabel 3. Uji hipotesis dilakukan dengan menggunakan regresi linier berganda one-tailed dengan tingkat $\alpha=5 \%$.

Dari Tabel 3 Panel A terlihat bahwa strategi bisnis berpengaruh signifikan terhadap besaran manajemen laba riil. Perusahaan dengan strategi bisnis defender memiliki besaran manajemen laba riil lebih besar dibanding dengan prospector, temuan ini mendukung $\mathrm{H}_{1}$. Kualitas audit mampu memoderasi pengaruh strategi bisnis terhadap manajemen laba riil. Hal ini terlihat dari koefisien STRATBIG yang signifikan pada $\alpha=5 \%$, temuan ini mendukung $\mathrm{H}_{2}$. Variabel kontrol yang berpengaruh signifikan terhadap besaran manajemen laba riil adalah market to book ratio, ukuran perusahaan (LnSize), dan debt.

Tabel 2 Panel B menunjukkan hasil untuk manajemen laba akrual. Dari hasil pengujian terlihat bahwa strategi bisnis perusahaan tidak berpengaruh signifikan terhadap besaran manajemen laba akrual. Kualitas audit yang diproksikan dengan BIG4 ditengarai mampu menurunkan besaran manajemen laba akrual (signifikan pada tingkat $\alpha=$ 10\%). Namun pada Tabel 2 panel B memperlihatkan bahwa BIG4 tidak mampu memoderasi 


\section{Strategi Bisnis dalam Praktik Manajemen Laba pada Perusahaan Manufaktur di Indonesia}

Permata Ayu Widyasari, Senny Harindahyani, Felizia Arni Rudiawarni

pengaruh strategi bisnis terhadap besaran manajemen laba akrual. Variabel kontrol yang berpengaruh positif terhadap besaran manajemen laba akrual adalah ukuran perusahaan (signifikan pada $\alpha=5 \%)$, utang (debt), turnover, dan standar akun- tansi yang mengadopsi IFRS (masing-masing signifikan pada $\alpha=10 \%)$. Variabel besaran akrual pada periode sebelumnya (AbsAbAcct-1) berpengaruh positif signifikan (pada $\alpha=1 \%$ ) terhadap manajemen laba akrual.

Tabel 2. Deskripsi Statistik

\begin{tabular}{|c|c|c|c|c|c|}
\hline & $\mathbf{N}$ & Minimum & Maximum & Mean & Std. Deviation \\
\hline AbsREMCFO & 395 & 0,001 & 0,919 & 0,085 & 0,094 \\
\hline AbsAbAcc & 395 & 0,001 & 0,887 & 0,068 & 0,083 \\
\hline STRAT & 395 & - & 1,000 & 0,494 & 0,501 \\
\hline BIG4 & 395 & - & 1,000 & 0,415 & 0,493 \\
\hline Mtb & 395 & $(9,029)$ & 53,590 & 2,283 & 5,093 \\
\hline LnSize & 395 & 16,632 & 33,095 & 26,741 & 3,503 \\
\hline growth & 395 & $(0,734)$ & 1,990 & 0,118 & 0,252 \\
\hline Ddebt & 395 & $(0,828)$ & 5,515 & 0,176 & 0,428 \\
\hline turnover & 395 & 0,015 & 4,141 & 1,002 & 0,602 \\
\hline IFRS & 395 & - & 1,000 & 0,749 & 0,434 \\
\hline AbsAbAcct-1 & 395 & 0,001 & 0,887 & 0,071 & 0,085 \\
\hline
\end{tabular}

Tabel 3. Hasil Uji Hipotesis dengan Regresi Linier Berganda

\begin{tabular}{lcccc}
\hline & Panel A: AbsREMCFO & \multicolumn{2}{c}{ Panel B: AbsAbAcc } \\
\hline (Constant) & B & T & B & 0,164 \\
STRAT & & & & $-1,426^{*}$ \\
BIG4 & 0,032 & $2,569^{* * *}$ & 0,002 & 0,159 \\
STRATBIG & 0,021 & $1,577^{*}$ & $-0,015$ & 0,325 \\
Mtb & $-0,045$ & $-2,310^{* *}$ & 0,002 & $1,742^{* *}$ \\
LnSize & 0,003 & $2,573^{* * *}$ & 0,000 & 0,531 \\
Growth & 0,003 & $1,802^{* *}$ & 0,002 & $1,518^{* *}$ \\
Ddebt & $-0,006$ & $-0,303$ & 0,008 & $1,564^{*}$ \\
Turnover & 0,029 & $2,486^{* * *}$ & 0,014 & $1,473^{*}$ \\
IFRS & 0,002 & 0,202 & 0,011 & $-1,128$ \\
D_2013 & $-0,002$ & $-0,165$ & 0,016 & $-1,815^{*}$ \\
D_2014 & 0,001 & 0,065 & $-0,012$ & $-2,202^{* *}$ \\
D_Consumer Industry & $-0,007$ & $-0,530$ & $-0,019$ & 0,712 \\
D_Miscellaneous Ind & $-0,005$ & $-0,413$ & $-0,022$ & $10,665^{* * *}$ \\
AbsAbAcct-1 & $-0,001$ & $-0,047$ & 0,006 & $10,877^{* * *}$ \\
F-Test & - & - & 0,467 & 0,260 \\
Adj R2 & & $2,362^{* * *}$ & & \\
\hline
\end{tabular}

Catatan:

Panel a)

AbsREMCFO $=\beta_{0}+\beta_{1}$ STRAT $+\beta_{2}$ BIG $4+\beta_{3}$ STRAT*BIG $+\beta_{4}$ Mtb $+\beta_{5}$ LnSize $+\beta_{6}$ growth $+\beta_{7}$ ddebt $+\beta_{8}$ turnover $+\beta_{9}$ IFRS $+\beta_{10-12}$ Year Dummies $+\beta_{13-14}$ Industry Dummies $+\varepsilon$

Panel b)

AbsAbAcc $=\beta_{0}+\beta_{1}$ STRAT $+\beta_{2}$ BIG $4+\beta_{3}$ STRAT $^{*}$ BIG $+\beta_{4}$ Mtb $+\beta_{5}$ LnSize $+\beta_{6}$ growth $+\beta_{7}$ ddebt $+\beta_{8}$ turnover $+\beta_{9}$ IFRS $+\beta_{10}$ AbsAbAcct- $1+\beta_{11-14}$ Year Dummies $+\beta_{14-15}$ Industry Dummies $+\varepsilon$ 


\section{Jurnal Keuangan dan Perbankan | KEUANGAN}

Vol. 21, No. 3, Juli 2017: 397-411

\section{Hasil Analisis Tambahan}

Analisis tambahan dilakukan pada penelitian ini dengan melakukan pangkategorian sampel antara perusahaan profit dengan perusahaan loss. Tabel 4 dan Tabel 5 menggambarkan hasil dari uji tambahan yang dilakukan. Hasil tersebut dilakukan melalui regresi linier berganda one-tailed.

Tabel 4 Panel B menunjukkan bahwa pada perusahaan dalam kondisi rugi, nampak bahwa strategi bisnis yang ditempuh manajemen tidak berpengaruh signifikan terhadap besaran manajemen laba riilnya. Variabel kontrol yang lain tidak berpengaruh signifikan terhadap besaran manajemen laba riil, kecuali untuk market to book ratio dan ukuran perusahaan pada perusahaan profit.

Tabel 5 menunjukkan hasil pengujian untuk besaran manajemen laba akrual. Pada perusahaan profit (Panel A) maupun perusahaan loss (Panel B) nampak bahwa besaran akrual pada tahun sebelumnya berpengaruh positif signifikan terhadap besaran manajemen laba akrual pada periode ini, dimana hasil ini mengkonfirmasi hasil pengujian yang diperoleh pada full sample pada Tabel 3.

Pada perusahaan loss, strategi bisnis berpengaruh negatif signifikan terhadap besaran manajemen laba akrual. Hal ini menunjukkan bahwa besaran manajemen laba akrual dari perusahaan defender lebih rendah dibanding dengan perusahaan prospector.

\section{PEMBAHASAN}

\section{Hubungan antara Strategi Bisnis dan Manajemen Laba}

Defender memiliki besaran manajemen laba riil lebih besar dibanding dengan prospector. Hal ini sesuai dengan penelitian Houqe et al. (2013). Penelitian ini menekankan manajemen laba pada manipulasi penjualan melalui percepatan waktu penjualan dengan meningkatkan harga diskon atau memberikan kredit ringan. Dibanding perusahaan prospector, defender mempunyai motif untuk mela-

Tabel 4. Analisis Tambahan untuk Absolut REMCFO Berdasarkan Kondisi Profit atau Loss

\begin{tabular}{lcccc}
\hline & \multicolumn{2}{c}{ PANELA: } & \multicolumn{2}{c}{ PANEL B: AbsREMCFO Sample LOSS } \\
& $\mathbf{B}$ & $\mathbf{t}$ & $\mathbf{B}$ & $\mathbf{t}$ \\
\hline (Constant) & $-0,032$ & $-0,689$ & 0,041 & 0,289 \\
STRAT & 0,040 & $3,066^{* * *}$ & $-0,009$ & $-0,182$ \\
BIG4 & 0,024 & $1,769^{* *}$ & $-0,039$ & $-0,684$ \\
STRATBIG & $-0,051$ & $-2,486^{* * *}$ & 0,015 & 0,217 \\
Mtb & 0,003 & $3,198^{* * *}$ & $-0,002$ & $-0,201$ \\
LnSize & 0,004 & $2,245^{* *}$ & 0,001 & 0,156 \\
Growth & 0,002 & 0,068 & $-0,016$ & 1,264 \\
debt & 0,031 & $1,871^{* *}$ & 0,035 & 1,066 \\
turnover & $-0,006$ & $-0,617$ & 0,030 & 0,789 \\
D_2012 & $-0,854$ & 0,033 & - \\
D_2013 & $-0,012$ & $-0,484$ & - & $-0,472$ \\
D_2014 & $-0,007$ & $-0,735$ & $-0,018$ & 1,101 \\
D_Consumer Industry & $-0,010$ & $-0,933$ & 0,068 & 0,364 \\
D_Miscellaneous Ind & $-0,012$ & $-0,354$ & 0,012 & 0,019 \\
IFRS & $-0,004$ & - & 0,001 & 0,536 \\
F test & - & $2,729^{* * *}$ & & $-0,099$ \\
Adj R2 & &, 065 & & \\
\hline
\end{tabular}

Catatan: *Sig pada $\alpha 10 \% ;{ }^{* *}$ Sig pada $\alpha 5 \%$; ${ }^{* *}$ Sig pada a $1 \%$ 


\section{Strategi Bisnis dalam Praktik Manajemen Laba pada Perusahaan Manufaktur di Indonesia}

Permata Ayu Widyasari, Senny Harindahyani, Felizia Arni Rudiawarni

kukan manajemen laba. Sebagai perusahaan yang mempunyai reputasi perusahaan yang lebih stabil, defender memiliki motivasi untuk menjaga reputasinya sehingga cenderung memenuhi ekspektasi investornya melalui manajemen laba. Tekanan ini tidak dimiliki oleh prospector yang cenderung mencari peluang pasar baru dengan menekankan inovasi.

Penelitian ini membuktikan bahwa terdapat hubungan antara pemilihan strategi bisnis defender dengan lebih tingginya tingkat manajemen laba karena ekspektasi investor terhadap perusahaan juga semakin tingginya. Disamping itu, semakin tinggi laju pertumbuhan perusahaan (diproksikan dengan market to book ratio), maka hal ini akan memicu perusahaan untuk melakukan manajemen laba. Hal ini sesuai dengan penelitian Skinner \& Sloan (2002) yang menyatakan bahwa perusahaan dengan peluang pertumbuhan yang tinggi memiliki tekanan untuk memenuhi earnings thresholds, sehingga perusahaan dengan potensi pertumbuhan yang tinggi akan cenderung melakukan manajemen laba.
Ukuran perusahaan berpengaruh positif signifikan terhadap manajemen laba riil. Temuan ini sesuai dengan Siregar \& Utama (2008), Wardhani \& Joseph (2010), dan Fanani (2014). Semakin besar skala perusahaan, maka mereka akan menghadapi tekanan yang lebih besar untuk melaporkan peningkatan laba dibandingkan perusahaan kecil (Kim et al., 2003). Barton \& Simko (2002) juga mengemukakan bahwa semakin besar ukuran perusahaan, maka tuntutan untuk memenuhi atau bahkan melampaui ekspektasi pasar juga akan semakin meningkat.

Debt berpengaruh positif signifikan terhadap besaran manajemen laba riil. Artinya, semakin tinggi tingkat utang perusahaan, maka pihak manajemen akan meningkatkan besaran manajemen labanya sebagai upaya untuk menghindari pelanggaran perjanjian utang (Watts \& Zimmerman, 1978).

Di lain pihak, strategi bisnis perusahaan tidak berpengaruh signifikan terhadap besaran manajemen laba akrual. Namun, besaran akrual pada periode sebelumnya berpengaruh positif sig-

Tabel 5. Analisis Tambahan untuk Absolut ACCRUAL Berdasarkan Kondisi Profit atau Loss

\begin{tabular}{lcccc}
\hline & Panel A: AbsAbAcc sample Profit & \multicolumn{2}{c}{ Panel B: AbsAbAcc sample Loss } \\
\hline & B & $\mathbf{t}$ & B & T \\
\hline (Constant) & & & $-0,063$ & $-1,960^{* *}$ \\
STRAT & 0,013 & 1,209 & $-0,086$ & $-2,288^{* *}$ \\
BIG4 & $-0,011$ & $-1,044$ & 0,091 & $1,922^{* *}$ \\
STRATBIG & $-0,007$ & $-0,435$ & 0,001 & 0,267 \\
Mtb & 0,001 & 0,693 & 0,004 & 1,278 \\
LnSize & 0,002 & $1,363^{*}$ & $-0,025$ & $-0,634$ \\
Growth & 0,013 & 0,743 & 0,014 & 0,886 \\
Debt & 0,026 & $1,944^{* *}$ & 0,045 & $2,391^{* *}$ \\
Turnover & 0,003 & 0,348 & 0,051 & $1,745^{* *}$ \\
D_2012 & 0,008 & 0,731 & $-0,010$ & $-0,394$ \\
D_2013 & 0,005 & 0,475 & - & - \\
D_2014 & $-0,003$ & $-0,265$ & $-0,034$ & $-0,820$ \\
D_Consumer Industry & $-0,021$ & $-2,069^{* *}$ & 0,000 & $-0,008$ \\
D_Miscellaneous Ind & 0,010 & 0,981 & 0,464 & $6,168^{* * *}$ \\
AbsAbAcct-1 & 0,497 & $8,368^{* * *}$ & 0,026 & 0,761 \\
IFRS & - & & $3,962^{* * *}$ \\
F Test & & $7,659^{* * *}$ & 0,382 \\
Adj R & & 0,222 & & \\
\hline
\end{tabular}

Catatan: *Sig pada $\alpha 10 \%$; **Sig pada $\alpha 5 \%$; ***Sig pada $\alpha 1 \%$ 
nifikan terhadap manajemen laba akrual. Hal ini menunjukkan bahwa pihak manajer cenderung melakukan manajemen laba akrual dari tahun ke tahun. Praktik tersebut didasari oleh berbagai motivasi manajemen laba termasuk motivasi untuk melaporkan konsistensi laba (Koonce \& Lipe, 2010). Variabel debt berpengaruh positif signifikan baik terhadap manajemen laba riil maupun manajemen laba akrual. Hal ini mendukung debt covenant hypothesis (Watts \& Zimmerman, 1978).

\section{Interaksi Kualitas Audit pada Hubungan antara Strategi Bisnis dan Manajemen Laba}

Perusahaan dengan strategi bisnis defender yang semula memiliki besaran manajemen laba riil yang lebih tinggi dibanding dengan prospector. Namun jika kualitas auditnya semakin baik (diproksikan dengan auditor BIG4), maka besaran manajemen laba riil ini semakin berkurang. Kualitas audit yang baik mampu mengurangi besaran manajemen laba riil dari perusahaan yang tergolong dalam kategori defender. Hal ini sesuai dengan hasil penelitian DeAngelo (1981) dan Becker et al. (1998) yang menunjukkan bahwa kualitas audit yang baik dapat menurunkan tingkat manajemen laba yang dilakukan oleh klien.

\section{Hasil Analisis Tambahan}

Analisis Tambahan untuk Absolut REMCFO berdasarkan kondisi profit atau loss defender memiliki besaran manajemen riil yang lebih tinggi dibanding dengan prospector pada sampel perusahaan yang mengalami profit. Sedangkan pada sampel perusahaan loss, strategi bisnis tidak berpengaruh signifikan terhadap besaran manajemen laba riil. Artinya perusahaan dengan strategi bisnis defender, melakukan manajemen laba riil agar dapat melaporkan profit pada laporan keuangannya.

Pada perusahaan profit, besaran manajemen laba riil dari perusahaan yang menjadi klien BIG4 lebih tinggi dibanding dengan klien non BIG4. Hal ini menunjukkan bahwa BIG4 belum tentu memiliki kualitas audit yang lebih baik dibanding dengan non BIG4 dalam hal mendeteksi manajemen laba riil yang dilakukan oleh kliennya. Hal ini disebabkan manajemen laba riil lebih sulit dideteksi dan dibuktikan oleh auditor dan regulator.

Namun pada sampel perusahaan profit, BIG4 mampu menurunkan besaran manajemen laba riil dari perusahaan defender. Hal ini menunjukkan bahwa BIG4 waspada terhadap perilaku manajemen laba dari kliennya yang sedang dalam posisi defender. Dengan adanya sumber daya dan pengalaman yang lebih baik, BIG4 memiliki kemampuan untuk mendeteksi adanya kecenderungan pihak manajemen untuk melakukan manajemen laba riil jika mereka dalam strategi bisnis defender.

Pada perusahaan dalam kondisi rugi, nampak bahwa strategi bisnis yang ditempuh manajemen tidak berpengaruh signifikan terhadap besaran manajemen laba riilnya. Artinya, perusahaan yang sudah dalam kondisi rugi dimana perusahaan tidak mampu lagi melakukan manajemen laba riil melalui manipulasi penjualan (AbsREMCFO), maka perusahaan tidak memiliki motivasi atau mungkin juga tidak memiliki ruang gerak yang cukup untuk melakukan manajemen laba riil. Pada perusahaan rugi juga terlihat bahwa jenis KAP tidak berpengaruh signifikan terhadap besaran manajemen laba riil dan jenis KAP (BIG4 atau non BIG4) tidak mampu memoderasi hubungan antara strategi bisnis dengan manajemen laba riil.

\section{Analisis Tambahan untuk Absolut Akrual berdasarkan Kondisi Profit atau Loss}

Besaran manajemen laba akrual dari perusahaan defender lebih rendah dibanding dengan perusahaan prospector. Pada perusahaan loss, besaran manajemen laba akrual dari klien BIG4 lebih rendah dibanding klien dari KAP non BIG4. Hal ini menunjukkan bahwa BIG4 mampu mendeteksi 


\section{Strategi Bisnis dalam Praktik Manajemen Laba pada Perusahaan Manufaktur di Indonesia}

Permata Ayu Widyasari, Senny Harindahyani, Felizia Arni Rudiawarni

manajemen laba akrual dari perusahaan loss dan memiliki daya tawar yang lebih baik dibanding dengan non BIG4 untuk bisa mengendalikan manajemen laba akrual dari klien mereka. Pada perusahaan loss, BIG4 mampu memoderasi hubungan antara strategi bisnis dan manajemen laba akrual. Variabel yang secara konsisten berpengaruh terhadap besaran manajemen laba akrual adalah besaran manajemen laba akrual pada periode yang lalu, baik pada full sample dan pada perusahaan profit maupun loss.

\section{SIMPULAN DAN SARAN}

\section{Simpulan}

Penelitian ini memberikan kontribusi bagi penelitian-penelitian manajemen laba, strategi bisnis, dan kualitas audit. Bisnis strategi memengaruhi perusahaan dalam berbagai hal termasuk berpengaruh pula terhadap posisi keuangan dan memberi motivasi untuk melakukan manajemen laba. Dari hasil penelitian ini dapat diambil beberapa kesimpulan. Pertama, perusahaan dengan strategi bisnis defender cenderung lebih agresif dalam melakukan manajemen laba riil dibanding dengan prospector. Hal ini terutama pada perusahaan defender dalam kondisi profit. Dalam kondisi loss, perusahaan defender memiliki besaran akrual yang lebih rendah dibanding dengan prospector. Kedua, kualitas audit yang tinggi (diproksikan dengan BIG4) mampu menekan besaran manajemen laba riil yang dilakukan oleh perusahaan defender. Pada saat perusahaan memilih strategi defender, hal ini membuat auditor BIG4 lebih waspada sehingga BIG4 mampu mendeteksi dan mengurangi besaran manajemen laba riil yang dilakukan oleh perusahaan defender. Namun temuan yang lain menunjukkan bahwa secara umum (baik pada pengujian fullsample maupun pada sampel profit dan loss), tanpa memperhitungkan strategi bisnis perusahaan, manajemen laba riil lebih sulit dideteksi karena hasil pengujian menunjukkan bahwa BIG4 tidak mampu menekan besaran manajemen laba riil yang dilakukan oleh klien. Sebaliknya manajemen laba akrual lebih mudah dideteksi, khususnya pada perusahaan loss. Implikasi dari penelitian ini menunjukkan bahwa motivasi manajemen laba juga dipicu oleh strategi bisnis perusahaan.

\section{Saran}

Penelitian ini dapat menjadi bahan pertimbangan bagi pengguna laporan keuangan, khususnya investor, untuk tidak semata-mata terpaku pada informasi laba. Pada perusahaan defender, laba yang tercantum pada laporan keuangan dapat mengandung manajemen laba. Namun, investor tetap dapat berinvestasi asalkan laporan keuangan perusahaan tersebut telah dievalusi dengan kualitas audit yang tinggi.

Penelitian ini memiliki beberapa keterbatasan yang dapat menjadi referensi untuk penelitian selanjutnya. Pertama, objek penelitian terbatas pada perusahaan manufaktur. Pada penelitian selanjutnya bisa diperluas pada sektor yang lain. Kedua, permodelan untuk manajemen laba hanya menggunakan 1 jenis model untuk masing-masing manajemen laba. Penelitian selanjutnya bisa menggunakan beberapa model manajemen laba agar dapat sekaligus membandingkan kemampuan model tersebut untuk menjelaskan hasil.

\section{DAFTAR PUSTAKA}

Arni, F. \& Sulistiawan, D. 2015. Can We Boost Stock Value Using Income-Increasing Strategy: The Case of Indonesia. International Journal of Applied Business and Economic Research, 13(7): 6093-6103.

Barton, J. \& Simko, P.J. 2002. The Balance Sheet as an Earnings Management Constraint. The Accounting Review, 77: 1-27.

Bartov, E., Givoly, D., \& Hayn, C. 2002. The Rewards to Meeting or Beating Earnings Expectations. Journal of Accounting and Economics, 33(2): 173-204. 


\section{Jurnal Keuangan dan Perbankan | KEUANGAN}

Vol. 21, No. 3, Juli 2017: 397-411

Bartov, E., Gul, F.A., \& Tsui, J.S.L. 2001. DiscretionaryAccruals Models and Audit Qualifications. Journal of Accounting and Economics, 30: 421-452.

Becker, C.L., Defond, M.L., Jiambalvo, J., \& Subramanyam, K.R. 1998. The Effect of Audit Quality on Earnings Management. Contemporary Accounting Research, 15(1): 1-24.

Bentley, K.A., Omer, T.C., \& Sharp, N.Y. 2013. Business Strategy, Financial Reporting Irregularities, and Audit Effort. Contemporary Accounting Research, 30(2): 780-817.

Burgstahler, D. \& Dichev, I. 1997. Earnings Management to Avoid Earnings Buyout Offers. Journal of Accounting And Economic, 18.

Caneghem, T.V. 2004. The Impact of Audit Quality on Earnings Rounding-Up Behaviour: Some UK Evidence. European Accounting Review, 13(4): 771-786.

Chung, R., Firth, M., \& Kim, J.B. 2005. Earnings Management, Surplus Free Cash Flow, and External Monitoring. Journal of Business Research, 58(6): 766-776.

Cohen, D.A., Dey, A., \& Lys, T.Z. 2008. Real and AccrualBased Earnings Management in the Pre- and PostSarbanes-Oxley Period. The Accounting Review, 83(3): 757-787.

Cohen, D.A. \& Zarowin, P. 2010. Accrual-Based and Real Earnings Management Activities around Seasoned Equity Offerings. Journal of Accounting and Economics, 50(1): 2-19.

Collings, S. 2011. Interpretattion and Application of International Standards on Auditing. New Delhi: Wiley.

Daniel, N.D., Denis, D.J., \& Naveen, L. 2008. Do Firms Manage Earnings to Meet Dividend Thresholds? Journal of Accounting and Economics, 45(1): 2-26.

DeAngelo, H., DeAngelo, L., \& Skinner, D.J. 2000. Special Dividends and the Evolution of Dividend Signaling. Journal of Financial Economics, 57(3): 309-354.

DeAngelo, L.E. 1981. Auditor Size and Audit Quality. Journal of Accounting and Economics, 3(3): 183-199.

Dechow, P.M., Sloan, R.G., \& Sweeney, A.P. 1995. Detecting Earnings Management. The Accounting Review, 70(2): 193-225.
Degeorge, F., Patel, J., \& Zeckhauser, R. 1999. Earnings Management to Exceed Thresholds. The Journal of Business, 72(1): 1-33.

Ettredge, M., Fuerherm, E.E., \& Li, C. 2014. Fee Pressure and Audit Quality. Accounting, Organizations, and Society, 39(4): 247-263.

Fanani, Z. 2014. Karakteristik Perusahaan dan Corporate Governance terhadap Manajemen Laba: Studi Analisis Meta. Jurnal Keuangan dan Perbankan, 18(2): 181-200.

Francis, J.R., Maydew, E.L., \& Sparks, H.C. 1999. The Role of Big 6 Auditors in the Credible Reporting of Accruals. Auditing: A Journal of Practice E Theory, 18(2): 17-34.

Francis, J. R. \& Yu, M.D. 2009. BIG4 Office Size on Audit Quality. The Accounting Review, 84(5): 1521-1552.

Graham, J.R., Harvey, C.R., \& Rajgopal, S. 2005. The Economic Implications of Corporate Financial Reporting. Journal of Accounting and Economics, 40(1-3): 373.

Harindahyani, S. 2015. Realitas Materialitas Audit dalam Teori dan Praktik. Jurnal Akuntansi Bisnis, 8(1): 120.

Healy, P. 1985. The Effect of Bonus Schemes on Accounting Decisions. Journal of Accounting and Economics, 7.

Higgins, D., Omer, T.C., \& Phillips, J.D. 2013. The Influence of a Firm's Business Strategy on its Tax Aggressiveness. Contemporary Accounting Research, 32(2): 674-702.

Holthausen, R.W., Larcker, D.F., \& Sloan, R.G. 1995. Annual Bonus Schemes and the Manipulation of Earnings. Journal of Accounting and Economics, 19(1): 29-74.

Houqe, M.N., Kerr, R., \& Monem, R. 2013. Business Strategy and Earning Quality. Working Paper.

Jensen, M.C. \& Meckling, W.H. 1976. Theory of the Firm: Managerial Behavior, Agency Costs, and Ownership Structure. Journal of Financial Economics, 3(4): 305-360.

Jermias, J. 2008. The Relative Influence of Competitive Intensity and Business Strategy on the Relationship between Financial Leverage and Performance. The British Accounting Review, 40(1): 71-86. 


\section{Strategi Bisnis dalam Praktik Manajemen Laba pada Perusahaan Manufaktur di Indonesia}

Permata Ayu Widyasari, Senny Harindahyani, Felizia Arni Rudiawarni

Jones, J.J. 1991. Earnings Management during Import Relief Investigations. Journal of Accounting Research, 29(2): 193-228.

Juanda, A. 2007. Pengaruh Risiko Litigasi dan Tipe Strategi terhadap Hubungan Antara Konflik Kepentingan dan Konservatisma Akuntansi. Disertasi. Universitas Gadjah Mada Yogyakarta.

Kim, Y., Liu, C., \& Rhee, S.G. 2003. The Effect of Firm Size on Earning Management. Journal College of Business Administration University of Hawaii, 6: 1-30.

Koonce, L. \& Lipe, M.G. 2010. Earnings Trend and Performance Relative to Benchmarks: How Consistency Influences Their Joint Use. Journal of Accounting Research, 48(4): 859-884.

Kothari, S.P., Leone, A.J., \& Wasley, C.E. 2005. Performance Matched Discretionary Accrual Measures. Journal of Accounting and Economics, 39: 163-197.

Kuan, L., Tower, G., Rusmin, R., \& Zahn, J.L.W.M.V.d. 2010. Related Party Transactions and Earnings Management. Jurnal Akuntansi \& Auditing Indonesia, 14(2): 115-137.

Lee, H.L. \& Lee, H. 2013. Do BIG4 Audit Firms Improve the Value Relevance of Earnings And Equity? Managerial Auditing Journal, 28(7): 628-646.

Matsumoto, D.A. 2002. Management's Incentives to Avoid Negative Earnings Surprises. The Accounting Review, 77(3): 483-514.

Miles, R.E. \& Snow, C.C. 1978. Organizational Strategy, Structure, and Process. New York: McGraw-Hill.

Miles, R.E. \& Snow, C.C. 2003. Organizational Strategy, Structure, and Process. Stanford: Stanford University Press.

Miles, R.E., Snow, C.C., Meyer, A.D., \& Coleman, H.J. 1978. Organizational Strategy, Structure, and Process. Academy of Management Review, 3(3): 546-562.

Prawitt, D.F., Smith, J.L., \& Wood, D.A. 2009. Internal Audit Quality and Earnings Management. The Accounting Review, 84(4): 1255-1280.

Roychowdhury, S. 2006. Earnings Management Through Real Activities Manipulation. Journal of Accounting and Economics, 42(3): 335-370.

Rusmin, R. 2010. Auditor Quality and Earnings Management: Singaporean Evidence. Managerial Auditing Journal, 25(7): 618-638.
Scott, W.R. 2015. Financial Accounting Theory. Toronto: Pearson.

Shireenjit, J., Christine, A.J., \& Keith, A.H. 2007. Earnings Management and the Audit Opinion: Evidence from Malaysia. Managerial Auditing Journal, 22(7): 688-715.

Siregar, S.V., Amarullah, F., Wibowo, A., \& Anggraita, V. 2012. Audit Tenure, Auditor Rotation, and Audit Quality: The Case of Indonesia. Asian Journal of Business and Accounting, 5(1): 55-74.

Siregar, S.V. \& Utama, S. 2008. Type of Earnings Management and the Effect of Ownership Structure, Firm Size, and Corporate Governance Practices: Evidence from Indonesia. The International Journal of Accounting, 43(1): 1-27.

Skinner, D.J. \& Sloan, R.G. 2002. Earnings Surprise, Growth Expectations, and Stock Returns or Don't Let an Earnings Torpedo Sink Your Portfolio. Review of Accounting Studies, 7(2-3): 289-312.

Snow, C.C. \& Hambrick, D.C. 1980. Measuring Organizational Strategies: Some Theoretical and Methodological Problems. Academy of Management Review, 5(4): 527-538.

Snow, C.C. \& Hrebiniak, L.G. 1980. Strategy, Distinctive Competence, and Organizational Performance. Administrative Science Quarterly, 25(2): 317-336.

Varadarajan, P.R. \& Clark, T. 1994. Delineating the Scope of Corporate, Business, and Marketing Strategy. Journal of Business Research, 31(2-3): 93-105.

Walker, O.C. \& Ruekert, R.W. 1987. Marketing's Role in the Implementation of Business Strategies: A Critical Review and Conceptual Framework. Journal of Marketing, 51(3): 15-33.

Wardhani, R. \& Joseph, H. 2010. Karakteristik Pribadi Komite Audit dan Praktik Manajemen Laba. Simposium Nasional Akuntansi XIII Purwokerto 2010.

Watts, R.L. \& Zimmerman, J.L. 1978. Towards a Positive Theory of the Determination of Accounting Standards. The Accounting Review, 53(1): 112-134.

Watts, R.L. \& Zimmerman, J.L. 1986. Positive Accounting Theory. Englewood: Prentice-Hall.

Yendrawati, R. \& Nugroho, W.A.S. 2012. Struktur Kepemilikan, Ukuran Perusahaan, dan Praktek Corporate Governance terhadap Manajemen Laba. Jurnal Keuangan dan Perbankan, 16(2): 188195. 